\title{
Correction to: Interconnecting History, African Indigenous Knowledge Systems and Science
}

\author{
Gloria Emeagwali and Edward Shizha
}

\author{
Correction to: \\ Chapter 1 in: G. Emeagwali \& E. Shizha (Eds.), African Indigenous \\ Knowledge and the Sciences, 3-11. \\ https://doi.org/10.1007/978-94-6300-515-9_1
}

The original version of this chapter was published with incorrect name of the chapter author as Gloria Jennings in the online version. This has now been corrected to Gloria Emeagwali.

The updated version of this chapter can be found at https://doi.org/10.1007/978-94-6300-515-9_1

G. Emeagwali \& E. Shizha (Eds.), African Indigenous Knowledge and the Sciences, C1. (C) 2016 Sense Publishers. All rights reserved. https://doi.org/10.1007/978-94-6300-515-9_18 